\title{
Współczesny rozwój konfucjanizmu na Bali w kontekście historycznym, politycznym i kulturowym
}

\section{Contemporary Developments of Confucianism in Bali in Historical, Political and Cultural Context}

\author{
Dobrochna Olszewska
}

\author{
KATEDRA ETNOLOGII I ANTROPOLOGII KULTUROWEJ, \\ UNIWERSYTET MIKOŁAJA KOPERNIKA W TORUNIU \\ UL. BOJARSKIEGO 1, 87-100 TORUŃ
}

dobrucha1@gmail.com

\begin{abstract}
Abstrakt
Od 2006 roku, po prawie trzech dekadach przerwy, konfucjanizm znalazł się ponownie wśród religii oficjalnie uznawanych przez państwo indonezyjskie. Zmiana ta postrzegana jest jako istotny krok $\mathrm{w}$ odchodzeniu od polityki dyskryminującej osoby pochodzenia chińskiego. Posługując się przykładem balijskim, artykuł omawia współczesny rozwój konfucjanizmu w Indonezji w kontekście praktyk religijnych i kultury mniejszości chińskiej, ideologii państwowej i prawa, polityki religijnej i etnicznej.
\end{abstract}

\begin{abstract}
From 2006 Confucianism is again one of the six staterecognized religions in Indonesia. This article aims to present its recent developments, using the example of Confucian community in Bali. It analyzes the problem in the context of religious practises and culture of the Chinese minority, state ideology and the law, religious and ethnic politics.
\end{abstract}




\section{Wprowadzenie}

W 1949 roku Holandia uznała niepodległość Republiki Indonezji, wyspiarskiego państwa powstałego w procesie dekolonizacji na terenach należących dotąd do Holenderskich Indii Wschodnich. Mimo, że zdecydowaną większość jego populacji stanowili wyznawcy islamu, nowe państwo nie było stricte muzułmańskie. Pośród pięciu wartości tworzących ideologiczne podstawy Indonezji znalazła się wiara w Boga rozumianego w kategoriach monoteistycznych, jednak kilkanaście lat później państwo uznawało oficjalnie sześć (właściwie pięć) religii: islam, buddyzm, protestantyzm i katolicyzm, hinduizm oraz konfucjanizm. Akceptacja dla tego ostatniego została następnie wycofana i przywrócona dopiero w 2006 roku, po prawie trzech dekadach przerwy. Zmienne losy konfucjanizmu wiązały się nie tylko z polityką religijną, ale też etniczną, jako że jego wyznawcami pozostają przede wszystkim osoby pochodzenia chińskiego (dalej określane też jako Tionghoa i chińscy Indonezyjczycy1). Ponowne uznanie było kolejną z decyzji władz kończących okres dyskryminacji wobec mniejszości chińskiej i często przedstawiane jest jako odzyskanie przez nią swobody praktyk religijnych i kulturowych. W tym przypadku relacje między ideologią, polityką, prawem, religią i kulturą są jednak bardziej złożone, co chciałabym pokazać na przykładzie procesów zachodzących na Bali, szczególnie w ciągu ostatnich dziesięciu lat ${ }^{2}$.

Poza Indonezją, system konfucjański często wymyka się jednoznacznej klasyfikacji. Nie chcę tu rozstrzygać toczącego się wśród naukowców sporu o jego charakter, szczególnie pamiętając o pewnej nierównoznaczności pojęć $\mathrm{w}$ różnych kulturach3. $\mathrm{Na}$ potrzeby tego artykułu przyjmuję stanowisko, że kwestię, czy konfucjanizm jest religią, powinno się pozostawić jego wyznawcom.

\footnotetext{
${ }^{1}$ Termin Tionghoa wywodzący się z dialektu hokkien oznacza Chińczyków, obecnie w Indonezji jest jednak częściej używany w znaczeniu Tionghoa peranakan i odnosi się do osób chińskiego pochodzenia. Termin ten po 1998 roku zastąpił w języku oficjalnym indonezyjskie słowo Cina, które nabrało negatywnych konotacji w okresie rządów gen. Suharto. Traktując to słowo jako nazwę pewnej grupy ludności, w dalszej części tekstu nie zapisuję go kursywą. Terminu chińscy Indonezyjczycy używam jedynie w kontekście niepodległej Indonezji.

2 Artykuł powstał na podstawie opracowań naukowych i własnych badań terenowych, prowadzonych na szerszy temat na Bali w okresie styczeń - czerwiec 2012 r. i wrzesień 2015 - luty 2016 r. Materiały pozyskałam w trakcie kilkudziesięciu wywiadów skategoryzowanych i swobodnych, w tym z osiemnastoma osobami bezpośrednio związanymi z konfucjańską świątynią w Denpasar, a także poprzez obserwację uczestniczącą. Brak odniesienia do literatury oznacza, że informacje pochodzą z materiałów zebranych w czasie badań.

3 Argumenty różnych badaczy za traktowaniem konfucjanizmu jako religii omawiają m. in.: R. Taylor, G. Arbuckle (1995); o relatywizmie kategorialnym w tym kontekście pisał: Z. Wesołoski (2001).
} 


\section{Rozwój religii konfucjańskiej na terenie dzisiejszej Indonezji}

W Holenderskich Indiach Wschodnich, udokumentowane próby szerzenia religii konfucjańskiej opartej na naukach i kulcie Konfucjusza jako proroka w środowiskach mniejszości chińskiej sięgają początków XX wieku. Tamtejszy ruch odrodzenia konfucjańskiego był zdominowany przez Tionghoa urodzonych na Jawie. Nie było to jednak zjawisko odosobnione; analogiczny ruch nie odniósł co prawda sukcesu w samym cesarstwie chińskim, ale spotkał się z pewnym oddźwiękiem w dzisiejszym Singapurze i Malezji (Coppel 1981: 182-183).

Pierwszą ogólnochińską organizacją w państwie kolonialnym, która powoływała się oficjalnie na religię konfucjańską, była Tiong Hoa Hwee Koan (Stowarzyszenie Chińskie, THHK). Utworzono ją w 1900 roku w Batawii (dzisiejszej Dżakarcie), między innymi, by propagować nauki świętych ksiąg jako prawdziwą religię Chińczyków i oczyszczenie kultury chińskiej z elementów niekonfucjańskich. Wkrótce jednak THHK poświęciła się przede wszystkim edukacji w języku chińskim, skłaniając się bardziej ku działalności o charakterze świeckim i nacjonalistycznym. Idee reformatorskie były nadal prezentowane na lamach specjalnego czasopisma „Li Po”, a dalszym rozwojem konfucjanizmu jako religii zajęły się Khong Kauw Hwee - Stowarzyszenia Konfucjańskie powstające lokalnie w niektórych jawajskich miastach. W 1923 roku ustanowiły one wspólny zarząd generalny w Bandungu (Khong Kauw Tjong Hwee). Członkowie z różnych miast kontynuowali próby uregulowania przebiegu obrzędów ślubnych i pogrzebowych, modlitw i zwyczajów codziennych, wydawali tłumaczenia ksiąg z kanonu konfucjańskiego oraz autorskie pisma przybliżające wartości konfucjańskie, utrzymując przy tym współpracę. Byli jednak stosunkowo nieliczni, a pierwsza chińska świątynia zamieniona jeszcze w 1903 roku w świątynię stricte konfucjańską - Boen Bio na ulicy Kapasan w Surabayi - przez lata pozostawała jedyną taką na terenie dzisiejszej Indonezji. Ruch nie tylko nie przyciągnął wielu zwolenników, ale też spotkał się z krytyką ze strony innych Tionghoa i z polemiką, w której kwestionowano także samą zasadność określania konfucjanizmu religią (Coppel 1981: 184-196).

Konfucjanizm w czystej formie był obcy lokalnym Chińczykom i przede wszystkim trudny do zdefiniowania, co wynikało z wielowiekowej współegzystencji tego systemu na terenach chińskich $\mathrm{z}$ taoizmem i buddyzmem, prowadzącej do przepływu różnych elementów i do powstawania form synkretycznych. Co więcej, wyrósł on na podłożu starszego światopoglądu i religijności chińskiej, stąd wiele kluczowych tradycji, włączając kult przodków, nie tyle wywodzi się z konfucjanizmu, ile zostało w nim także zaakceptowane (Tan 1983: 217-252). W świątyniach budowanych przez chińskich imigrantów na wyspach obecnej Indonezji, lokalnie czczono deifikowanych przodków bądź różnych chińskich bogów, nie były więc one przypisane konkretnie do konfucjanizmu (Coppel 2981: 
182). Część przybyszy stopniowo włączała do swoich religijnych praktyk także elementy kultur lokalnych, dodatkowo rozwijały się wcześniej nieznane kulty. Religijność Tionghoa pozostawała w pewnym stopniu ortopraktyczna czy pragmatyczna - zorientowana raczej na właściwe praktyki i skuteczność treści religijnych w życiu codziennym ${ }^{4}$.

Wśród jawajskich społeczności chińskich, niektóre zmiany proponowane przez konfucjańskie stowarzyszenia religijne odbierano więc jako zaniedbanie i odejście od tradycji przodków, a próby formalizowania jako zbędne. Do tego dochodziły oskarżenia o wpływy chrześcijańskie. Ostatecznie zarząd generalny w Bandungu przestał istnieć. Niektóre lokalne ośrodki przetrwały jednak do czasów niepodległej Indonezji. W 1965 roku ówczesny prezydent Sukarno wydał regulację, na podstawie której konfucjanizm został oficjalnie jedną z sześciu indonezyjskich religii. Po przejęciu władzy przez generała Suharto, w antykomunistycznej atmosferze, Kong Kauw Hwee jako stowarzyszenia religijne mogły początkowo kontynuować swoją działalność i rozwój. W 1967 roku na kongresie w Solo przyjęły indonezyjską nazwę Majelis Agama Khonghucu Indonesia (Rada Religii Konfucjańskiej Indonezji, MAKIN), a ustanowiony przez nie zarząd - Majelis Tinggi Agama Khonghucu Indonesia (Naczelna Rada Religii Konfucjańskiej Indonezji, MATAKIN). Główne założenia ruchu pozostały tożsame z tymi sprzed drugiej wojny światowej, choć jak twierdzi Leo Suryadinata, jego działania zmierzały $\mathrm{w}$ kierunku indonezjanizacji $\mathrm{i}$ instytucjonalizacji konfucjanizmu, $\mathrm{z}$ praktykami zorganizowanymi na zasadach zbliżonych do muzułmańskich i chrześcijańskich - ze świątyniami, w których dominuje wizerunek Konfucjusza, a kult, z cotygodniowymi nabożeństwami, jest odprawiany przez kapłanów (Suryadinata 2005: 79-81). Taka forma oraz podkreślanie roli kultu najwyższego Boga Tian sprawiły, że system ten stał się bliższy państwowej wizji prawdziwej religii.

W 1979 roku decyzją rządu konfucjanizm przestał być jednak oficjalnie uznawaną religią, co wpisywało się w ówczesną politykę asymilacyjną względem mniejszości chińskiej.

\section{Balijska społeczność konfucjańska}

Krótko przed wspomnianym wyżej zarządzeniem, idee rozwijające się na Jawie zdążyły jeszcze zaowocować powstaniem konfucjańskiej świątyni na sąsiedniej wyspie Bali, w mieście Denpasar. Pokolenie jej założycieli jest już nieobecne, stąd trudno dokładnie odtworzyć okoliczności towarzyszące tej inicjatywie. Wiadomo, że Khongcu Bio przy ulicy Bisma otwarte $9 \mathrm{X}$ 1977 r. od początku swojego istnienia było świątynią poświęconą religii konfucjańskiej. Przejawia się to także w architekturze. Sakralne budynki chińskie na terenie Indonezji, choć licznie odwiedzane w dni świąteczne, są zazwyczaj stosunkowo niewielkie, gdyż modlitwy w nich mają głównie

4 Por.: Wesołowski 2001: 290. 
charakter indywidualny5. Świątynia przy ulicy Bisma odznacza się na tle innych balijskich świątyń chińskich wielkością i rozplanowaniem przystosowanymi do wspólnych modlitw i nabożeństw. Centralną część ołtarza zajmuje posąg proroka Konfucjusza. W związku z sytuacją polityczną, w pierwszych dekadach działanie świątyni było bardzo ograniczone, choć zdaniem moich rozmówców wciąż możliwe w wąskim gronie. Upadek rządów Suharto w 1998 roku i rozpoczęta wówczas reformacja, już w pierwszych latach przyniosły ożywienie, istotne znaczenie dla podejmowanych działań miała jednak wspomniana decyzja z 2006 roku.

Obecnie w świątyni w każdą niedzielę odbywają się nabożeństwa odprawiane przez kapłanów według ściśle ustalonego rytuału, opartego przede wszystkim na składaniu ofiar, wspólnych modlitwach i nauczaniu. $\mathrm{Na}$ pulpitach lawek leżą śpiewniki zawierające pieśni religijne w języku indonezyjskim do melodii chińskich. W cyklu rocznym, oprócz obchodów świąt kalendarza chińskiego kultywowanych powszechnie we wszystkich tradycyjnych świątyniach, 27 dnia VIII miesiąca chińskiego kalendarza odprawiane jest także specjalne nabożeństwo $\mathrm{z}$ okazji urodzin proroka Konfucjusza. Rozpoczyna się ono przed świtem procesją. Następnie jedna osoba wygłasza polecenia, kierując składaniem ofiar, następnie, odczytany zostaje list modlitewny, po czym rozpoczyna się właściwe nabożeństwo, na które składają się modlitwa, wprowadzenie głównego opiekuna świątyni, odczytanie opowieści o cudownym poczęciu i narodzeniu Konfucjusza oraz odpowiednie pieśni. 18 dnia II miesiąca odprawiana jest uroczystość upamiętniająca śmierć proroka; jej przebieg jest taki sam, zmienia się treść odczytywanego listu, opowieści i wybór pieśni. Wszystko to odbywa się według szczegółowych schematów-instrukcji opracowanych przez Naczelną Radę Religii Konfucjańskiej Indonezji, MATAKIN i rozpowszechnianych w specjalnych broszurach ${ }^{6}$.

W świątyni prowadzona jest także działalność ukierunkowana na edukację młodszych pokoleń i zaszczepianie $\mathrm{w}$ nich odpowiednich wzorców zachowania. Te cele realizowane są przede wszystkim w ramach szkoły niedzielnej dla dzieci w różnym wieku, w której nauka odbywa się według oficjalnego curriculum nauki religii konfucjańskiej w szkołach indonezyjskich. (Niektóre balijskie szkoły wprowadziły już lekcje konfucjanizmu, ale zmiany te nie objęły jeszcze wszystkich placówek). W każdą ostatnią niedzielę miesiąca część czasu lekcyjnego poświęcana jest na nabożeństwo, w którego przygotowanie i odprawienie angażują się starsi uczniowie. Oprócz tego, w ramach promowania kultury chińskiej, szkoła prowadzi dla chętnych naukę języka mandaryńskiego oraz tańców 'mandaryńskich', do których choreografię opracowuje nauczycielka,

5 O chińskiej architekturze sakralnej w Indonezji, także w kontekście jej funkcji pisał: Handidoto 2009.

6 Miałam okazję porównać przebieg ceremonii z okazji narodzin Konfucjusza ze scenariuszem zawartym $\mathrm{w}$ wydawnictwie MATAKIN: Tata agama dan tata laksana upacara agama Khonghucu, vol. XXVIII, no. 4-5. 
głównie na podstawie filmów zamieszczonych na serwisie youtube. Przy świątyni działa także młodzieżowy zespół barongsai (tradycyjnego tańca chińskich lwów) a od jesieni 2015 roku organizowane są wieczorne spotkania młodzieży. Ich pomysł został zaczerpnięty $\mathrm{z}$ przykładu stowarzyszeń młodzieżowych innych religii, które wydają się sprawdzać w rozwijaniu religijności i osobowości młodych.

Świątynią zarządzają jej opiekunowie, kapłani i przedstawiciel lokalnej rady MAKIN. Oprócz nich, w życie Khongcu Bio przy ulicy Bisma zaangażowane jest także grono nauczycieli-wolontariuszy oraz innych działaczy i stałych bywalców copiątkowych wieczornych spotkań dyskusyjnych. Spotkania te, poza celami towarzyskimi, służą przede wszystkim jako okazja do wymiany opinii na różne kwestie religijne i zagadnienia $\mathrm{z}$ zakresu konfucjańskiej etyki, filozofii i tradycji. Często uczestnicy przychodzą z przygotowanymi pytaniami i grupa stara się wspólnie rozwiązać wątpliwości. Tych jest sporo, ponieważ niemal wszyscy konfucjanizm w takiej formie znają jedynie z własnych dociekań, lektur głównie publikacji MATAKIN, lub zetknęli się z nim dopiero na ulicy Bisma. Członków tej niewielkiej społeczności łączy jednak przekonanie o konieczności powrotu do prawdziwej tradycji chińskiej, co jest dla nich równoznaczne $\mathrm{z}$ kultywowaniem konfucjanizmu oczyszczonego z elementów niekonfucjańskich. Dla niektórych te dążenia mają jedynie wymiar osobisty, ale aktywni działacze pracują na rzecz przemiany społeczności chińskiej na Bali, a przynajmniej w najbliższej okolicy. Podkreślają, że na Bali zatracony został prawdziwy charakter religii chińskiej. Jak to określiła jedna z nauczycielek, „Szkoła pomaga teraz wrócić do właściwych praktyk, bo w domu często są już niejasne, pomieszane".

Tym samym tradycje przywiezione na Bali przez chińskich imigrantów i przekazywane $\mathrm{w}$ rodzinach $\mathrm{z}$ pokolenia na pokolenie, są podważane jako nie dość autentyczne, nie dość chińskie. Zwyczaje te, choć wiele $\mathrm{z}$ nich zachowało ciągłość nawet $\mathrm{w}$ czasach dyskryminacji, ulegały oczywiście także stopniowo różnym zmianom, chociażby w wyniku adaptacji do warunków lokalnych i pewnej akulturacji. Przedmiotem troski i krytyki działaczy są jednak wpływy buddyzmu i inne niekonfucjańskie wierzenia pochodzące $\mathrm{z}$ kraju przodków, a nie elementy hinduizmu balijskiego. Te tłumaczone są przez moich rozmówców jako spadek po wcześniejszych pokoleniach, którego nie odważyliby się już zignorować, jak na przykład przydomowe balijskie świątynki dla opiekuna miejsca (penungguh karang) czy dla balijskich przodków, o które trzeba wciąż dbać i których obecność zobowiązuje do składania ofiar. Częściowa lokalna akulturacja jest postrzegana też jako naturalna konsekwencja życia na Bali i wspólnej historii społeczności chińskiej i Balijczyków7. Podkreślane są

\footnotetext{
$7 \mathrm{~W}$ tym kontekście przytaczana jest często historia o małżeństwie pięknej Chinki Kang Ching Wi z władcą Batur, Sri Jaya Pangus, która miała się wydarzyć w XII wieku. Interesująco w kontekście kultury balijskiej analizuje ją: V. Gottowik (2010).
} 
także podobieństwa między konfucjanizmem a hinduizmem, a jednocześnie różnice między tym pierwszym a buddyzmem.

Sytuacja ta jest przynajmniej częściowo efektem ideologii i polityki religijnej oraz etnicznej niepodległej Indonezji. Zasada wiary w jednego Boga wśród podstaw ideologicznych państwa oznacza, że nawet teraz religia chińska w synkretycznej formie, jest $\mathrm{w}$ pewnym stopniu marginalizowana, choć dawniej była najbardziej powszechna wśród ludności Tionghoa. Istnieje, co prawda, organizacja Tridharma (Trzy Nauki) i podlegające pod nią świątynie łączące kulty taoistyczne, buddyjskie i elementy konfucjańskie, ale takiej przynależności religijnej nie można wpisać w dowodzie tożsamości. Do roku 1979, kiedy uznawany był konfucjanizm, osoby kultywujące wciąż tradycyjne wierzenia w formie synkretycznej deklarowały się oficjalnie jako konfucjaniści, tak jak wyznawcy „czystej” religii opartej na świętych księgach czczący proroka. W późniejszych latach rządów Suharto, w ramach wykorzeniania tradycji chińskich, świątynie chińskie próbowano zamienić na buddyjskie, jednocześnie starano się jednak odłączyć „indonezyjski” buddyzm od buddyzmu chińskiego (Suryadinata 2005: 83-85). W obowiązkowej w dokumentach rubryce „religia” osoby pochodzenia chińskiego zamieniały nieuznawany już konfucjanizm na buddyzm, który wydawał się najbliższy ich kulturze, na Bali czasem na hinduizm, część konwertowała się też wówczas - przynajmniej formalnie - na chrześcijaństwo, rzadziej islam. Deklaracja posiadania „prawdziwej” religii miała chronić przed podejrzeniami o powiązania komunistyczne.

W tych okolicznościach, niektórym młodym osobom trudno było rozwinąć poczucie przynależności religijnej, utożsamianie się z konkretnym światopoglądem. Dzieci z rodzin kultywujących synkretyczne tradycje a zadeklarowanych jako buddyjskie, w ramach obowiązkowej edukacji religijnej w szkole musiały uczestniczyć w lekcjach hinduizmu, chrześcijaństwa czy też islamu. To zamieszanie religijne tylko powierzchownie zmniejszyło się, kiedy do szkół wprowadzono także buddyzm. Od tej pory dzieci te uczęszczały na lekcje, na których uczono ich buddyzmu Theravady, w wersji dostosowanej do polityki religijnej Indonezji. Wracając ze szkoły, mogły więc odczuwać dysonans między nauką a religią praktykowaną $\mathrm{w}$ domu, zawierającą jedynie pewne elementy buddyzmu chińskiego (z tradycji Mahayany), co prowadziło u niektórych do poczucia zagubienia.

Znaczna część osób spotkanych przeze mnie w Khongcu Bio w Denpasar to właśnie zagubienie wskazywała jako powód swoich samodzielnych poszukiwań, które w późniejszym życiu doprowadziły je na ulicę Bisma. Tamte doświadczenia przyczyniły się też do ich przekonania, że buddyzm jest obcy kulturze chińskiej. Jednocześnie lata dyskryminacji etniczności chińskiej tłumaczą, według nich, zanik właściwego pojmowania tradycyjnej religii u Tionghoa deklarujących się przed 1979 rokiem jako konfucjaniści. Przekonanie to jest silne, chociaż u wielu rodzin oficjalne ograniczenia nie wpłynęły znacząco na rytuały domowe, a omawiana świątynia była pierwszą taką na wyspie, co wskazuje nie tyle na zanik, a na 
bardzo ograniczony wcześniejszy zasięg konfucjanizmu w takiej formie. Tylko dwie nauczycielki wskazały, że tak rozumianą religię zaszczepiono im $\mathrm{w}$ domu; rodzice jednej $\mathrm{z}$ nich byli także zaangażowani $\mathrm{w}$ powstanie świątyni. Troje nauczycieli zostało konfucjanistami stosunkowo niedawno, ze względu na wybór partnerów życiowych i obowiązujący w Indonezji wymóg prawny, by zawierający związek małżeński byli wyznawcami jednej religii ${ }^{8}$. Wśród nich są dwie etniczne Balijki oraz Tionghoa pochodzący z katolickiej społeczności na Flores, dawniej uczący się w seminarium duchownym. Obecnie nie tylko aktywnie działa na rzecz rozwoju świątyni, ale też jest tam jedną $\mathrm{z}$ osób o najbardziej pogłębionej wiedzy konfucjańskiej, którą studiował wraz z nauczycielem przysłanym do Khongcu Bio z Jawy. Tym samym, wielu członków przyświątynnej społeczności wyznaje i praktykuje konfucjanizm w szerzonej przez siebie formie dopiero od kilku - kilkunastu lat.

W celu propagowania prawdziwej tradycji, jak już wspomniałam, w świątyni odprawiane są ceremonie przeprowadzane na podstawie ścisłych instrukcji z broszur, nieznane wcześniej ani odprawiającym, ani reszcie społeczności chińskiej na Bali. Liturgia nabożeństw i tak zinstytucjonalizowany kult jest więc zjawiskiem wciąż nowym na Bali i stosunkowo nowym w Indonezji w ogóle, powrót do prawdziwej tradycji - odtwarzaniem jej, czy też pewnego o niej wyobrażenia, przy braku naturalnej ciągłości, a także tworzeniem nowej tradycji.

Należy jednak uwzględnić także wymiar reformatorski działań społeczności Khongcu Bio. Z tej perspektywy, propagowanie jedynego właściwego modelu religii konfucjańskiej ma na celu rozwój duchowy i moralny jednostek w oparciu o dawne wartości, a tym samym wzmocnienie więzi społeczności chińskiej i poprawę życia. W takim kontekście omawiane zjawisko jest nie tyle dążeniem do czystości kulturowej, co próbą wyeliminowania elementów, które w odczuciu działaczy hamują rozwój. Stąd istotniejsze jest skuteczne przekazanie pożądanych treści niż to, czy sama forma przekazu jest tradycyjna.

Zwrócenie się ku „autentycznej” kulturze przodków wiąże się też $\mathrm{z}$ budowaniem swojej tożsamości. Jednoczesna akceptacja w swoich praktykach pewnych elementów balijskich może zatem wskazywać na rozwój tożsamości lokalnej moich rozmówców (a więc nie tylko chińskiej i indonezyjskiej, ale też balijskiej). Może też oczywiście świadczyć o poprawności w imię dobrych relacji z grupą dominującą i tym samym, bezpieczeństwa.

Obecnie na Bali religia konfucjańska w przedstawionej tu formie ma wciąż niewielki zasięg. W nabożeństwach stricte konfucjańskich uczestniczą przede wszystkim osoby zaangażowane w życie świątyni aktywnie bądź poprzez piątkowe spotkania, ich rodziny, niektórzy starsi uczniowie. Na ceremoniach, w których brałam udział, każdorazowo

8 Według obowiązującego wciąż prawa $\mathrm{z} 1974$ r. związek małżeński może zostać zarejestrowany jedynie, jeśli ceremonia zaślubin odbyła się zgodnie $\mathrm{z}$ religią obydwu zawierających go stron. 
obecnych było nie więcej niż pięćdziesiąt osób. Świątynia jest liczniej odwiedzana 1 i 15 dnia każdego miesiąca kalendarza chińskiego oraz z okazji najważniejszych świąt cyklu rocznego, przede wszystkim przez Tionghoa z sąsiedztwa. Uczęszczają oni tam przede wszystkim dlatego, że jest to najbliższa świątynia chińska w ich okolicy, zdarza im się jednak modlić także $w$ innych, zarówno podlegających obecnie pod organizację Tridharma, jak i przemianowanych w czasach Suharto na buddyjskie. Jeśli w swoich domach mają ołtarzyk do chińskich bóstw, znajdzie się wśród nich raczej figura Buddy czy bogini Kuan Im - bogini miłosierdzia, popularnej żeńskiej formy bodhisatvy Avalokitesvara - niż Konfucjusza. Oprócz tego, ich domostw prawie na pewno chronią ofiary składane hinduistycznym opiekunom. Część z nich przyprowadza swoje dzieci do niedzielnej szkoły. Wśród wiernych zdarzaja się jednak także nieliczni puryści religijni, którzy studiują zagadnienia filozofii i etyki konfucjańskiej $\mathrm{z}$ książek, nie uczestniczą jednak $\mathrm{w}$ nabożeństwach czy spotkaniach dyskusyjnych. Khongcu Bio przy ulicy Bisma pozostaje jedyną stricte konfucjańską świątynią na wyspie. Osoby związane z innymi balijskimi świątyniami chińskimi, z którymi rozmawiałam, działalność omawianej społeczności albo pośrednio krytykowały albo zbywały z pewnym lekceważeniem. Takie napięcia między świątyniami wydają się także rezultatem niedawnej historii.

\section{Zakończenie}

Przedstawione przeze mnie zjawisko pozostaje więc marginalne wśród chińskich Indonezyjczyków powyżej dwudziestego roku życia. Pomimo to, warto zwrócić na nie uwagę i śledzić jego rozwój wśród młodszych pokoleń, na które może mieć większy wpływ, chociażby poprzez lekcje konfucjanizmu, w czasie których ponownie treścią nauczania nie jest religia $\mathrm{w}$ formie znanej $\mathrm{z}$ domu. $\mathrm{W}$ tym momencie trudno jeszcze przewidzieć, jak te działania wpłyną na postrzeganie przez młodych tradycji kultywowanych przez rodziców, a także na dalszy rozwój ich tożsamości i kultury. 


\section{Bibliografia}

Coppel, C. A. 1981. The Origins of Confucianism as an Organized Religion in Java, 1900-1923. Journal of Southeast Asian Studies, vol. 12, no. 1: Ethnic Chinese in Southeast Asia, pp. 179-196.

Gottowik, V. 2010. Transnational, Translocal, Transcultural: Some Remarkson the Relations between Hindu-Balinese and Ethnic-Chinese in Bali. Journal of Social Issues in Southeast Asia, vol. 25, no 2, pp. 178-212.

Handidoto. 2009. Perkembangan arsitektur Tionghoa di Indonesia. w: b.d., Peranakan Tionghoa Indonesia: sebuah perjalanan budaya. Jakarta.

Suryadinata, L. 2005. Buddhism and Confucianism in Contemporary Indonesia: Recent Developments. w: T. Lindsey, H. Pausacker (Ed.) Chinese Indonesians. Remembering, Distorting, Forgetting. Singapore, pp. 77-94.

Tan, C.-B. 1983. Chinese Religion in Malaysia: a General View. Asian Floklore Studies, vol. 42, pp. 217-252.

Tata agama dan tata laksana upacara agama Khonghucu, vol. 28, no. 4-5. Taylor, R. Arbuckle, G. 1995. Confusianism. The Journal of Asian Studies, vol. 54, no. 2, pp. 347-354.

Wesołowski, Z. 2001. Konfucjanizm. w: H. Zimoń (Ed.) Religia w świecie wspótczesnym. Lublin: Towarzystwo Naukowe Katolickiego Uniwersytetu Lubelskiego, pp. 289-306. 